\title{
MURCHA BACTERIANA DO GERÂNIO CAUSADA POR Ralstonia solanacearum BIOVAR 2/RAÇA 3 NO BRASIL
}

\author{
Irene M. G. Almeida ${ }^{1}$ \\ Suzete A. L. Destéfano ${ }^{1}$ \\ Júlio Rodrigues Neto ${ }^{1}$ \\ Valdemar A. Malavolta Jr. ${ }^{2}$
}

\section{RESUMO}

A murcha bacteriana causada por Ralstonia solanacearum foi observada em plantio comercial de gerânio, localizado no município de Vargem Grande Paulista, Estado de São Paulo. As plantas apresentavam sintomas de amarelecimento e necrose das folhas, seguida de morte. As linhagens de $R$. solanacearum isoladas foram caracterizadas como pertencentes ao biovar $2 /$ raça 3 , e se mostraram patogênicas à batata $\mathrm{e}$ ao tomate. Onze variedades comerciais de gerânio foram avaliadas com relação à murcha bacteriana, sendo que todas foram consideradas suscetíveis. Este é o primeiro relato da ocorrência de $R$. solanacearum em gerânio no Brasil. Linhagens da bactéria encontram-se depositadas na Coleção de Culturas IBSBF sob números de acesso 1708, 1711 e 1712.

Palavras-chave: Pelargonium zonale, Ralstonia solanacearum, biovar/ raça.

\footnotetext{
${ }^{1}$ Instituto Biológico, Caixa Postal 70, CEP 13001-970, Campinas, SP, Brasil. E-mail: gatti@biologico.br

${ }^{2}$ Instituto Agronômico, Caixa Postal 28, CEP 13001-970, Campinas, SP, Brasil.
} 


\section{ABSTRACT}

\section{SOUTHERN BACTERIAL WILT OF GERANIUM CAUSED BY Ralstonia solanacearum BIOVAR 2/RACE 3 IN BRAZIL}

Bacterial wilt on geranium caused by Ralstonia solanacearum was observed in a commercial plantation located at Vargem Grande Paulista, State of São Paulo, Brazil. The plants showed symptoms of wilting and yellowing of the leaves followed by necrosis and death. The strains isolated belong to biovar 2 / race 3 , and were also pathogenic to potato and tomato by artificial innoculations. Eleven commercial varieties of geranium were also tested for bacterial wilt, and all of them were susceptible to the pathogen. This is the first report of the occurrence of $R$. solanacearum affecting geranium in Brazil. Cultures were deposited at IBSBF Culture Collection under accession number 1708, 1711 and 1712.

Key words: Pelargonium zonale, Ralstonia solanacearum, biovar/race.

\section{INTRODUÇÃO}

Durante o mês de abril de 2002, foi observado, em cultivo comercial localizado na região de Vargem Grande Paulista, Estado de São Paulo, plantas de gerânio (Pelargonium zonale hib.) com sintomas que se iniciavam com amarelecimento a partir das folhas superiores, seguidos de murcha e morte das plantas (Figura 1). As plantas doentes apresentavam ainda uma descoloração dos tecidos vasculares das raízes e caule.

A doença ocasionava perdas significativas, e os sintomas verificados sugeriam ser causados por bactérias, o que foi confirmado por meio de observações dos tecidos ao microscópio óptico.

A literatura registra que sintomas de descoloração vascular de tecidos de raízes e caule em gerânio podem ser ocasionados por Xanthomonas hortorum pv. pelargonii ou por Ralstonia solanacearum (Dougherty et al., 1974; Munnecke, 1954; Strider et al., 1981), sendo que $R$. solanacearum não causa manchas foliares, e X. hortorum pv. pelargonii pode ocasioná-las ou não. No Brasil, já foi relatada a 


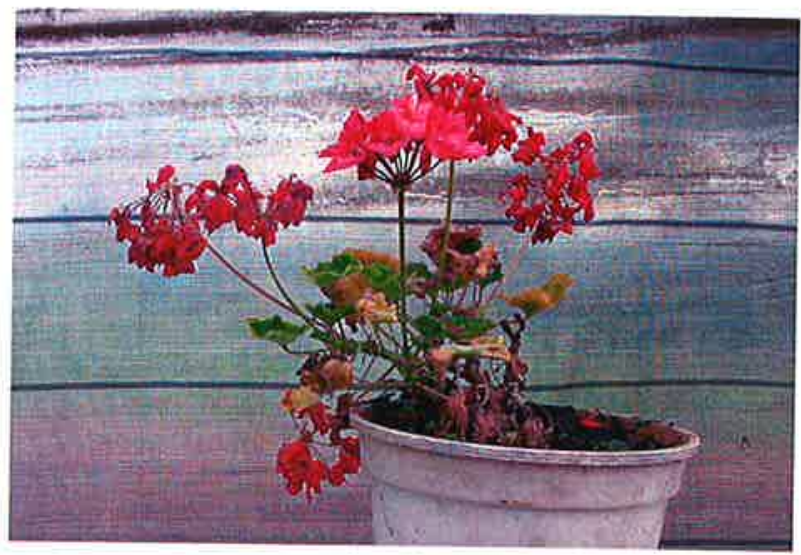

Figure 1. Sintomas de amarelecimento e murcha em folhas e flores de gerânio. Infecção natural por Ralstonia solanacearum.

ocorrência de Xanthomonas sp. afetando Pelargonium hortorum, induzindo sintomas de descoloração vascular e podridão de ramos, com posterior morte das plantas (Sugimori et al., 1987). Posteriormente, o agente causal foi identificado como X. hortorum pv. pelargonii (M.H. Sugimori, comunicação pessoal). No caso ora estudado, não foram verificados sintomas de manchas em folhas e dos isolamentos efetuados foram obtidas colônias típicas de Ralstonia solanacearum.

Linhagens de $R$. solanacearum são diferenciadas em cinco raças, de acordo com a gama de hospedeiros e em cinco biovares, conforme a utilização de vários dissacarídeos e alcoóis-hexoses (Hayward, 1964; Hayward et al., 1991).

Com a finalidade de se confirmar a etiologia da doença, foi elaborado o presente estudo.

\section{MATERIAL E MÉTODOS}

Culturas bacterianas e condições de cultivo - a partir de folhas e haste de plantas apresentando sintomas da doença foram efetuados isolamentos em meio TZC (Kelman, 1954) e selecionadas três linhagens 
bacterianas (IBSBF* 1708, 1711 e 1712) que foram empregadas nos testes efetuados. Somente colônias virulentas, selecionadas em meio TZC e multiplicadas em meio Nutriente Ágar (Peptona bacteriológica 3g; Extrato de carne 5g; Cloreto de sódio 5g; Ágar 15g; Água destilada qsp $1000 \mathrm{~mL}$ ) foram utilizadas nos experimentos. As linhagens foram preservadas por meio de liofilização e/ou em suspensões em tubos com água destilada esterilizada.

Determinação do biovar - as linhagens bacterianas isoladas de gerânio foram caracterizadas bioquimicamente, por meio da oxidação/ utilização dos dissacarídeos celobiose, lactose e maltose e dos alcoóishexoses dulcitol, manitol e sorbitol, em combinação com a utilização de tartarato de sódio (L-tartarato) e reação após infiltração em folha de fumo (Nicotiana tabacum), conforme preconizado por Hayward (1994) e Hayward et al. (1991).

Testes de patogenicidade - duas plantas de gerânio cultivadas em vasos foram inoculadas com cada linhagem bacteriana, por meio da deposição de uma gota (cerca de $30 \mu \mathrm{L}$ ) do inóculo (suspensão bacteriana em água esterilizada com aproximadamente $10^{7} \mathrm{UFC} / \mathrm{mL}$ ) na axila das folhas (terceira folha contada a partir do ápice), e posterior ferimento provocado com agulha. Plantas testemunhas sofreram o mesmo tratamento, utilizando-se água esterilizada. Além das plantas de gerânio, foram também inoculadas plantas de batata (Solanum tuberosum) e de tomate (Lycopersicum esculentum).

Avaliação de variedades comerciais - onze variedades comerciais de gerânio, fornecidas pela empresa Lazzeri for Plant, foram avaliadas quanto ao comportamento em relação à murcha bacteriana. Plantas das variedades Avenida, Boogy, Brasil 98, Ópera, Rocky Mountain Red, Rokoko, Rumba 98, Samba, Tango Hot Pink, Tango Orange e Tango Pink, cultivadas em vasos e no estágio de quatro a cinco folhas totalmente expandidas, foram inoculadas por meio de rega do solo com $30 \mathrm{~mL}$ de suspensão bacteriana $\left(9,4 \times 10^{7} \mathrm{UFC} / \mathrm{mL}\right)$ e posterior

*IBSBF, Coleção de Culturas do Laboratório de Bacteriologia Vegetal, Instituto Biológico, Campinas, SP, Brasil. 
corte das raízes unilateralmente, a 3-4 $\mathrm{cm}$ das hastes das plantas. As avaliações foram feitas semanalmente, de acordo com escala de notas de 1-5 proposta por Strider (1982), onde: 1= ausência de sintomas; $2=$ enfezamento; $3=$ clorose ou necrose das folhas; $4=$ murcha das folhas, e $5=$ morte da planta.

\section{RESULTADOS E DISCUSSÃO}

Os isolamentos efetuados em meio TZC (Kelman, 1954) resultaram em colônias fluidas, brancas com o centro rosa, típicas de Ralstonia solanacearum, sendo confirmadas como pertencentes a esta espécie bacteriana por alguns outros testes bioquímicos como Gram-negativas, produção de levan, arginina dihidrolase, hidrólise de amido e de esculina negativos, redução de nitrato a nitrito, oxidase, urease e catalase positivas (Schaad et al., 2002). Com base nos resultados das reações de oxidação/ utilização dos carbohidratos (positivos para celobiose, lactose e maltose; negativos para dulcitol, manitol e sorbitol) (Tabela 1), bem como da utilização de L-tartarato e indução de hipersensibilidade em folhas de fumo, essas linhagens foram caracterizadas como pertencentes ao biovar 2/raça 3. As linhagens bacterianas estudadas encontram-se depositadas na Coleção de Culturas IBSBF.

Os testes de patogenicidade efetuados com as variedades de gerânio induziram sintomas de amarelecimento e/ou murcha das folhas

Tabela 1. Resultados dos testes bioquímicos utilizados para diferenciação dos biovares de Ralstonia solanacearum.

\begin{tabular}{lcccccc}
\hline & Isolado de & \multicolumn{5}{c}{ Biovar } \\
\cline { 3 - 7 } Oxidação/utilização & gerânio & I & II & III & IV & V \\
\hline Maltose & $+*$ & - & + & + & - & + \\
Lactose & + & - & + & + & - & + \\
Celobiose & + & - & + & + & - & + \\
Manitol & - & - & - & + & + & + \\
Sorbitol & - & - & - & + & + & - \\
Dulcitol & - & - & - & + & + & - \\
\hline * resultado positivo; & - resultado negativo & & &
\end{tabular}


após 14 dias. Aos 21 dias, a maioria das variedades apresentaram murcha generalizada (nota 4), sendo que aos 30 dias todas elas exibiram sintomas de seca e morte das plantas (nota 5), não ocorrendo diferenças entre as mesmas, indicando que as variedades foram suscetíveis à bactéria. Tal fato foi também observado por Strider (1982) que verificou a susceptibilidade de vinte variedades comerciais de gerânio a essa espécie bacteriana, em plantios localizados na Carolina do Norte (EUA).

As inoculações realizadas em batata e tomate também induziram sintomatologia de murcha após 14 dias.

Do ponto de vista epidemiológico, um aspecto interessante envolve as linhagens de $R$. solanacearum biovar 2T/raça 3 isoladas de gerânio. Anteriormente reconhecida como de ocorrência em condições de temperatura amenas e praticamente específica à batata (patogênica ao tomateiro sob condições muito especiais de concentração de inóculo no solo), o biovar 2 /raça 3 parece ter uma faixa de hospedeiros mais ampla, confirmando as hipóteses de Roncal et al. (1999) e Sinigaglia et al. (2001). Por outro lado, a velocidade na expressão dos sintomas pode significar uma adaptação da bactéria a temperaturas mais elevadas.

Embora não se conheça a raça das linhagens isoladas por Strider et al. (1981), os primeiros relatos de $R$. solanacearum infectando gerânio em nível mundial, indicam este patógeno como da raça 1 (Hayward, 1964). O primeiro e único relato na Europa do biovar 2 /raça 3 infectando gerânio foi descrito por Janse em 1996. Somente em 2002, o biovar 2 / raça 3 da bactéria foi identificado nos EUA, proveniente de plantas de gerânio e que se mostrou altamente patogênico à batata (Williamson et al., 2002).

A bactéria $R$. solanacearum é um patógeno de ampla distribuição no globo, causando doença em culturas de grande importância econômica e social. Ainda, a murcha bacteriana pode se tornar fator limitante na produção de diversas culturas, como é o caso do amendoim, banana, batata, beringela, fumo e tomate, entre outras.

A ocorrência de $R$. solanacearum em plantas de gerânio comercializadas em vasos aliada ao fato dessa linhagem ter sido patogênica a solanáceas de importância econômica (como a batata e o tomate) sugerem a possibilidade que essa ornamental possa ser um hospedeiro alternativo e fonte de inóculo para culturas de importância 
econômica, podendo se instalar em campos de produção a partir de plantios protegidos, ocasionando inclusive problemas relacionados com quarentena.

Este é o primeiro relato da ocorrência desta bactéria infectando gerânio em nosso país.

\section{REFERÊNCIAS BIBLIOGRÁFICAS}

DOUGHERTY, D.E.; C.C. POWELL \& P.O. LARSEN, 1974. Epidemiology and Control of Bacterial Leaf Spot and Stem Rot of Pelargonium hortorum. Phytopathology, 64: 1081-1083. HAYWARD, A.C., 1964. Characteristics of Pseudomonas solanacearum. Journal of Applied Bacteriology, 27: 265-277.

HAYWARD, A.C.; L. SEQUEIRA; E.R. FRENCH; H. EL-NASSAR \& U. NYDEGGER, 1991. Tropical Variant of Biovar 2 of Pseudomonas solanacearum. Phytopathology, 82: 608. JANSE, J.D., 1996. Potato Brown Rot in Werstern Europe - History, Presence Occurrence and Some Remarks on Possible Origin, Epidemiology and Control Strategies. European and Mediterranean Plant Protection Organization Bulletin (Bull. OEPP/EPPO Bull.), 26: 679-985.

KELMAN, A., 1954. The Relationship of Pathogenicity in Pseudomonas solanacearum to Colony Appearance on a Tetrazolium Medium. Phytopathology, 44: 693-695.

MUNNECKE, D.E., 1954. Bacterial Stem Rot and Leaf Spot of Pelargonium. Phytopathology, 44: 627-632.

RONCAL, J.; L. GUTARRA \& S.PRIOU, 1999. Rapid Differentiation of Strains of Ralstonia solanacearum by Restriction Analysis of PCR-Amplified Fragments. Bacterial Wilt Newsletter, (16): p. 7-10.

SCHAAD, N.W.;.B. JONES; W. CHUN (eds), 2001. Laboratory Guide for Identification of Plant Pathogenic Bacteria. 3 ed. St. Paul: APS Press,. 373 p.

SINIGAGLIA, C.; E.M.B. LOPES; I.M.G. ALMEIDA \& J. RODRIGUES NETO, 2001. Bacterial Wilt of Summer Squash (Cucurbita pepo) Caused by Ralstonia solanacearum in the State 
of São Paulo, Brazil. Summa Phytopathol; 27(2):251-251. STRIDER, D.L.,1982. Susceptibility of Geraniums to Pseudomonas solanacearum and Xanthomonas campestris pv. pelargonii. Plant Disease, 66: 59-60.

STRIDER, D.L.; R.K. JONES \& R.A. HAYGOOD, 1981. Southern Bacterial Wilt of Geranium Caused by Pseudomonas solanacearum. Plant Disease, 65: 52-53.

SUGIMORI, M.H.; I.J.A. RIBEIRO; T.A. NUCCI \& L.H.S. CASTRO, 1987. Ocorrência de Podridão Bacteriana do Gerânio Causada por Xanthomonas sp. no Estado de São Paulo. Summa Phytopathologica, 13: 10.

WILLIAMSON, L.; K. NAKAHO; B. HUDELSON \& C. ALLEN, 2002. Ralstonia solanacearum Race 3, Biovar 2 Strains Isolated from Geranium are Pathogenic on Potato. Plant Disease, 86: 987-991. 